\title{
Sustainable Fisheries Management in the Indian Ocean: The Way Forward
}

\author{
Jayanath Colombage
}

\begin{abstract}
The Oceans cover 71\% of the earth's surface and contains 97\% of the planet's water. This is the life support system of the earth. The Ocean is the main protein supplier for the humankind. The Indian Ocean is a warm water ocean and well regulated by monsoons and currents. Large number of rivers and tributaries flow into this ocean, making it rich with minerals, seaweeds and planktons, which sustain the fish stocks. Man-made pollution and climate change can be detrimental to the sustenance of a balanced marine eco-system. Further, Illegal, Unreported and Unregulated (IUU) fishing combined with destructive fishing methods can deplete this valuable protein source. Issues and conflicts in delimitation of maritime boundaries and fishermen not respecting even internationally or bilaterally established maritime boundaries are impediments to effective fisheries management. The Indian Ocean is vast and the third largest ocean in the world. The population of the Indian Ocean is around 2.5 billion. However, we must be mindful of the need to have a sustainable ocean based economic model, that will not over exploit the finite fishery resources but will continue to provide the much-needed protein sources to this large population, not only at present times but even in the future. Non-management of fisheries by states and non-adherence to rule based maritime order by non-state actors engaged in fisheries could have ramifications on traditional and human security aspects for the region. Fishing boats and some fishermen could be involved with various maritime crime activities for monetary or ideological gains, and, depletion of fisheries resources due to overfishing can have a direct impact on human security of the Indian Ocean littorals, as the main livelihood and economic activities of the coastal populations are connected to the ocean based resources. There were many instances of the fishermen being exploited by terrorist groups. Hence the management of fisheries in a sustainable manner is important for the Indian Ocean, as the peaceful co-existence of the nations depends on the continued Blue Economic models where the fisheries is managed and harvested in a sustainable manner.
\end{abstract}

Keywords: Fisheries Management, Indian Ocean, Traditional and Human security, Sustainable Blue Economy 


\section{Introduction}

"Over the years, I have seen the power of the oceans to excite, feed, and sustain people. I have also seen them undergo a growing onslaught of attacks, from destructive fishing practices to rising acidification".

\section{Frances Beinecke}

The Indian Ocean is the third largest ocean in the world. Consisting of 29 littoral states and six Island nations, this ocean is home to one-third of the world's population. The Indian Ocean is a warm water ocean and well regulated by two monsoons and ocean currents. A large number of rivers and tributaries flow into this ocean, making it rich with minerals, seaweeds and planktons, which sustain rich and balanced bio-diversity and large fish stocks. The ocean is known to play a vital role as the major source of vital nutrients such as protein for life in the ocean, and ultimately for the largest human population in the Indian Ocean Region. The countries in this ocean are characterized by varying degrees of economic, political and cultural practices. There is diversity in fishing practices, boat and gear used and even the type of fish caught within this region. There is a lack of data and transparency in fishing activities as well. The fisheries management systems are also different from one country to another. The task of studying the efficiency of sustainable fisheries management in this ocean is hence difficult ${ }^{1}$. There are a number of maritime border disputes in the region and some fishermen quite often transgress these maritime boundaries and engage in fishing citing that these are traditional fishing grounds for them. Given that the biological diversity of the oceans has decreased dramatically, leading to the destruction of marine habitats and coastal ecosystem, sustainable fisheries management becomes catalyst to the conservation and management of marine ecosystems. Hence, this paper seeks to shed some light on the present status of fisheries management in the Indian Ocean by highlighting some of the many maritime border issues and to suggest the way forward for Indian Ocean states to develop proper management methods.

1 "A stable step towards sustainable fishing in the Indian Ocean," (2012), https://ec.europa.eu/fisheries/stable-step-towards-sustainable-fishingindianocean_mt 


\section{Legal Framework for Management of Fisheries}

The main internationally accepted legal framework for fisheries management is provided in the United Nations Convention on the Law of the Sea (UNCLOS 111, 1982) ${ }^{2}$, part five under the Exclusive Economic Zone (EEZ). The Article 56 of the said convention indicates the rights, jurisdiction and duties of the coastal state in the EEZ. The coastal state has the right to explore, exploit and conserve as well as manage natural resources within the EEZ. The coastal state has a responsibility to protect and preserve the marine environment. The Article 61 of the Convention describes the conservation of the living resources. As per this Article, the coastal state shall determine the allowable catch of living resources and taking into best scientific evidence available, shall ensure proper conservation and management measures that the maintenance of the living resources is not endangered by over-exploitation. The same article also indicates the necessity of cooperation of coastal states and competent international organizations in achieving sustainable management of fisheries. Such measures shall also be designed to restore populations of harvested species at levels, which can produce the maximum sustainable yield, as qualified by relevant environmental and economic factors, including the economic needs of the coastal fishing communities and special requirement of developing state, and taking into consideration the fishing patterns, the interdependence of stocks and any generally recommended international minimum standards. The Article 62 of the UNCLOS indicates that the coastal state shall promote the objective of optimum utilization of the living resources in the EEZ without prejudice to article 61. Moreover, Article 63 talks about fish stocks occurring within the EEZ of two or more coastal states or both, within the EEZ and in an area beyond and adjacent to it. UNCLOS clearly indicates that the main responsibility of managing the fisheries within the EEZ lies on the coastal state. UNCLOS Part VII, Section 2 provides the legal framework for sustainable fisheries in the high seas. This provides guidelines for qualified freedom of fishing on the high seas, the obligation of the state to cooperate in the conservation and management of living resources of the high seas and obligation on states to conserve living resources on the high seas. Although the legal framework for management of the fisheries was provided by the UNCLOS, it has been

2 "United Nations Convention on the Law of the Sea," (1982), http://www.un.org/depts/los/convention_agreements/texts/unclos/unclos_e.pdf 
observed that many coastal states do not follow these guidelines and engaged in overfishing.

The United Nations Conference on Environment and Development (UNCED) in 1992 observed that there is a lack of sufficient cooperation between states, inadequate management of high seas fisheries, overcapitalization in the fishing industry, excessive fleet size, overexploitation of resources, problems of unregulated fishing, vessels re-flagging to escape controls, insufficiently selective fishing gears and unreliable database as major causes for concern. Having studied the situation, the UN came up with 'the UN Fish Stock Agreement' (1995) ${ }^{3}$. This Provides a detailed regime for the conservation and management of straddling fish stocks and highly migratory fish stocks on the high seas areas through fish stocks on the high seas areas through implementation, development and elaboration of provisions in UNCLOS (Articles 63, para.2 and 64, and Part VII, (Articles 63, para.2 and 64, and Part VII, Section 2).

There are other international instruments providing for sustainable fisheries management as well;

- 1993 Food and Agriculture Organization (FAO) Compliance agreement

- 1995 FAO Code of Conduct for Responsible fisheries

- FAO International Plan of Action

- Management of fishing capacity

- Illegal, Unregulated and Unreported (IUU) fishing

- Reykjavic declaration on responsible fisheries

- UN general Assembly resolutions to provide for Sustainable Fisheries

Despite all these international instruments, conventions and activities of international organizations, threats to sustainable fisheries management continue, in particular overfishing, IUU fishing and destructive fishing practices.

${ }^{3}$ United Nations Conference on Straddling Fish Stocks and Highly Migratory Fish Stocks. (1995), http://www.un.org/depts/los/convention agreements/texts/fish_stocks_agreement/CONF164_37.htm 
Legal Implications of Illegal, Unreported, Unregulated (IUU) Fishing: According to the United Nations Food and Agriculture Organization (FAO), International Plan of Action to Prevent, Deter and Eliminate Illegal, Unreported and Unregulated fishing (FAO, 2001) 4;

- Illegal fishing refers to activities: Conducted by national or foreign vessels in waters under the jurisdiction of a State, without the permission of that State, or in contravention of its laws and regulations;

- Unreported fishing refers to fishing activiti es: Which have not been reported, or have been misreported, to the relevant national authority, in contravention of national laws and regulations; or

- Unregulated fishing refers to fishing activities: In areas or for fish stocks in relation to which there are no applicable conservation or management measures and where such fishing activities are conducted in a manner inconsistent with State responsibilities for the conservation of living marine resources under international law.

Maritime Borders and IUU fishing in the Indian Ocean: The paper will briefly examine four maritime border disputes and issue of IUU fishing in the Indian Ocean, especially in South Asian region.;

a. Swatch off Karachi, Sir Creek and Gujarat between the Maritime borders of India and Pakistan. As per Bana "deltaic region in the South East of Karachi is rich in marine life. Most of the Indian fishermen sneak into area Swatch, approximately 70 nm South of Karachi within EEZ of Pakistan. High quality of shrimps, lobsters and fish, especially Red Snapper, commonly called 'Lal Pari' by the fishermen, are abundantly present in this area which tempt Indian fishermen to take the risk (Bano,

${ }^{4}$ Food and Agriculture Organization (FAO) of the United Nations, International plan of action to prevent, deter and eliminate Illegal, Unreported and Unregulated fishing. (2001), http://www.fao.org/docrep/003/y1224e/y1224e00.htm 
2008)5. The Indian fishermen venture into Pakistani territory in search of a better catch and get arrested.

b. Sir Creek. Sir Creek is a 96-km tidal sanctuary on the border of Pakistan and India. This Creek joins into the Arabian sea and separate the state of Gujarat (India) and Sindh province(Pakistan). Sir Creek is situated in the marshes of the Rann and Kutch $\left(\right.$ Misra,2001) ${ }^{6}$. The dispute on this border between India and Pakistan has been an intractable one despite many attempts by both the sides to find a mutually agreeable solution. Whilst the dispute has been going on, the river has changed its course considerably ${ }^{7}$. If there is an agreement on the Sir Creek, both sides will have to adjust some sea areas, which is part of their EEZ. It is believed that the prospects of finding minerals, oil and gas below the sea bed has aggravated the dispute over the Sir Creek. The fishermen from both the countries are carrying out fishing in the traditional manner using small boats, with limited navigational aid. As there is no clear demarcation of the maritime boundary near Sir Creek, quite often the fishermen from both sides find themselves on the other side of the boundary and get arrested. Most of these fishermen are daily wage earners and their earnings could also depend on the amount of the catch. When they are arrested, they have to languish in jail for months and in some cases for years, until their case is heard through the slow legal system in both the countries. This is a major human security issue as fishing is the main livelihood of these coastal populations. This impact on the education, health and wellbeing of the fishermen from both sides of the divide.

c. Gujarat. Meantime, Pakistani fishermen also goes over to the Indian side of the maritime border to catch Pomfret, Garupa, prawns and shrimp etc. Indian coast guard has enhanced surveillance in this area with ships and aircraft mainly fearing

5 Sheher Bano, Fishing in Troubled Waters, http://www.intermedia.org.pk/pdf/pak_afghan/Sheher_Bano.pdf

${ }^{6}$ Misra. A. The Sir creek boundary Dispute: A victim of India-Pakistan Linkage Politics, (2001), https://www.dur.ac.uk/ibru/publications/ download/?id=177

${ }^{7}$ Khan, R.A. (2007). Sir Creek: The Origin and Development of The Dispute Between Pakistan And India. IPRI Journal, 7 (2): 1-13. 
infiltration by terrorists and arrests some of the Pakistani fishing boats. The fate of these fishermen is also very similar to those captured by Pakistan Maritime Security Agency.

d. Palk Bay and Gulf of Mannar in India-Sri Lanka
International Maritime Boundary Line. A shallow and narrow strip of sea called the 'Palk Bay' and the 'Gulf of Mannar' separates the two Indian Ocean states; India and Sri Lanka. There is a clearly demarcated, mutually agreed upon and legally binding International Maritime Boundary Line (IMBL), separating the territorial waters of the two countries. Until the signing of IMBL agreements in 1974 and 1976, fishermen from coastal districts of both countries used this sea, mainly for traditional fishing. There was a harmonious coexistence between these communities for a long time. However, Tamil Nadu fishermen changed their fishing methods in the late 1970s and upgraded to steel hulled fishing vessels and engaged in bottomtrawling in order to boost production. Continuous bottom trawling on the Indian side of the IMBL resulted in depleting fish stocks therein. Gradually, these trawlers began to cross over to the Sri Lankan side of the IMBL. The newly introduced Indian trawlers were much bigger and more powerful than traditional crafts, as they had to trawl and recover nets heavy with the catch. The fishermen of northern Sri Lanka found it extremely difficult to venture into the sea during the days when Indian trawlers were poaching, as they feared damage to their boats and fishing gear, as well as safety for their lives. During the time of the conflict, the Sri Lankan government was compelled to restrict fishing by local fishermen in the north and the east due to security concerns. However, the Indian trawlers continued to bottom trawling in Sri Lankan waters regardless, at times reaching 2-3 nautical miles off the Sri Lankan coast. This situation was effectively exploited by the Liberation Tigers of Tamil Eelam (LTTE), who used Indian trawlers to ferry their cadres, fuel, and explosives; mainly from the southern Indian coast to northern, north-western and north-eastern coasts of Sri Lanka. However, the number of Indian trawlers operating in Sri Lankan waters was relatively less during this period, as they feared misidentification as LTTE agents by the Sri Lanka Navy. With the end of the conflict in Sri Lanka, and the gradual 
resettlement of displaced personnel, local fishermen wished to recommence their livelihood activities and what they encountered was a large hostile Tamil Nadu trawler fleet plundering their resources. With the fishery conflict gaining a new significance, both governments continued discussions at various levels to find an amicable long lasting solution. However, to-date, there has been no solution or even a common agreement on the issues affecting fishermen from both countries. In this situation, there is a clearly agreed upon International Maritime Boundary line (IMBL), but the Indian fishermen cross the IMBL and carry out destructive bottom trawling, with severe damages to the marine ecosystem claiming that they are fishing in traditional fishing grounds. Despite efforts by both the governments at various levels; from ministerial to fishermen level, a solution has not been found and the destruction continues 8 .

There are many instances of Sri Lankan fishermen poaching in the waters of other countries in the Indian Ocean, mainly looking for tuna, which has a big export as well as domestic market in Sri Lanka. These IUU fishing by Sri Lankan fishermen has resulted in an imposition of a ban by the European Union (EU) on Sri Lanka's seafood exports to EU countries. Sri Lanka had to work hard to meet the conditions to comply with EU requirements.

\section{Fishing Boats, Terrorism and Maritime Crimes}

Fishermen are the only category of people who can leave the shores of a country without any immigration or custom control and return back to the shores. Fishermen do not restrict their fishing to territorial waters or even to the EEZ. They fish in international waters and even in the EEZ of other states at times. This situation gives them a unique advantage of leaving a country, staying at sea for a number of days and return back to the country without proper checks been made by enforcement authorities. There are many instances of fishermen being engaged in smuggling of contrabands, narcotic substances, weapons and even humans. Trafficking of narcotic drugs by fishing boats is a common occurrence in Sri Lankan waters. These narcotic drugs are believed to be

8 Bernard Goonetilleke, and Jayanth Colombage, Indo-Sri Lanka Fishery Conflict: An Impediment to Development and Human Security (2017), http://cimsec.org/indo-srilanka-fishery-conflict-impediment-development-human-security/30113 
in transit to another country and also for the use of the local population. Only a limited number of these boats are apprehended and majority of them evade arrest and carry out their transfer. Doole observes that "According to the Sri Lanka Navy, the heroin dealers from foreign countries have been engaged in large scale drug trafficking activities in collaboration with the drug dealers in Sri Lanka. It was further revealed that the consignments of drugs are transferred by foreign vessels to the sea areas of Sri Lanka, and brought ashore by multi-day fishing trawlers in the guise of engaging in fishing. This stock is then transferred to Colombo via the Southern Expressway. This drug racket has been recognised as a well-organised business running without detection of the authorities" (2016) ${ }^{9,10 .}$

Human trafficking is another maritime crime undertaken by some fishing boats. Dissanayake writing to the Global Press Journal describe the situation with regard to human smuggling as; "Sri Lanka has long relied heavily on its fishing industry, and many of the country's coastal villages are home to expert fishermen and skippers. Skippers who have deep-sea boats equipped for multiple-day expeditions, say they'were approached by smugglers who need experienced teams to ferry illegal migrants from Sri Lanka to Australia. More than 6,400 Sri Lankans arrived, unauthorized, in Australia, in 2012, according to a November 2014 research paper by the Australian Department of Immigration and Border Protection" (2015) ${ }^{11}$. There are many source countries for irregular migration by sea in the Indian ocean. Most of these migrants use fishing boats to escape from their own country and undertake a journey to another country, which they believe will accept them or as a gateway to another sanctuary.

9 Cassendra Doole, "Sri Lanka: A Heroin Hub?" Roar, (2016), http://roar.lk/reports/srilanka-heroin-hub/

${ }^{10}$ Jayanth Colombage, Asymmetric Warfare at Sea: The Case of Sri Lanka. (Lambert Academic publishing, Saarbrucken, Germany, 2016).

${ }^{11}$ Chathuri Dissanayake, "Smugglers Rely on Sri Lankan Fishing Captains and Their Boats to Move Migrants to Australia", Global Press Journal, (November $8^{\text {th }}, 2015$ ), https://globalpressjournal.com/asia/sri_lanka/smugglers-rely-on-sri-lankan-fishingcaptains-and-their-boats-to-move-migrants-to-australia/ 
Fishing boats can also be exploited by terrorist organizations. In the case of Sri Lankan conflict, the Liberation Tigers of Tamil Eelam(LTTE) exploited fishing boats belonged to both India and Sri Lanka. During the initial stages of the conflict inthe late 1970s and early 1980s, the LTTE used small fishing boats to transfer their cadres between training bases in Tamil Nadu, India and the northern coast of Sri Lanka. Later on, they used fishing boats to transfer war-fighting materials across the Palk Bay. As the organization grew and fighting with the government forces increased, the LTTE began using large fishing trawlers either purchased or commandeered, to carry out mid-sea transfer of weapons, ammunition and other materials from LTTE supply ships to the coastal areas under their control (Colombage,2016). On some occasions the LTTE used Indian fishing trawlers for their missions. These transfer's by using fishing trawlers were very successful for the LTTE and the Sri Lanka Navy found it extremely difficult to monitor the entire coast around the country as there were a few thousand multi-day fishing trawlers operating around the island. This situation was mitigated to some extent by introducing a system of fishing marshalling points around the coast to check departure and arrival of fishing boats. The LTTE used fishing boats to gather intelligence of naval patrols, military installations and other vital targets on the coastal areas as well. The 2008 Mumbai attack also exemplifies the vulnerability of fishing boats to exploitation by terrorist elements. Hence it can be concluded that fishing trawlers can be used for various maritime crime and terrorist activities and therefore can be considered as a non-traditional security threat, if not properly managed.

\section{Threats to Sustenance of Fisheries}

Fisheries resources in the oceans are a renewable source. However, it should be considered as a finite resource, as overexploitation and some other measures can have made certain fisheries go extinct. At the same time, unlike on land, it has also become arduous a task to record and evaluate the degree of destruction and loss caused to these rare species of fish. Some of the reasons that challenge the sustenance of the fisheries resources range from deliberate destructive practices to accidental ones resulting in the rapid disappearance of fisheries resources. Some of these harmful practices are;

a. Offshore Oil and Gas. There are many risks associated with oil and gas exploration and related extraction processes. There can be accidental oil spills and release of gas at sea during 
storage and shipping. Harbours and terminals facilitating storage and loading of oil and gas have the threat of accidental release. This could harm human life, fisheries and wildlife and especially the coastal regions.

b. Commercial and Recreational Fishing. Overfishing for global seafood trade is a major threat to the sustenance of the oceans. Illegal, Unreported and Unregulated (IUU) fishing is taking place in the world's oceans, despite various international and regional conventions and regimes. Some fisheries also employ destructive fishing methods such as bottom trawling, use of explosives, banned nets. etc. These methods are harmful to the reproductive cycle of various species of fish; their habitats can destroy an entire marine eco-system. Also, there are large numbers of recreational fishing activities taking place in the oceans. The biggest source of protein to the mankind is at huge risk of overfishing and irreparable damage caused to the marine eco system.

c. Aquaculture Projects. Aquaculture production meets more than half the global seafood need now. Presently much of the production is land based. However, there is a possibility for this business to venture in to the coastal areas. This could result in habitat destruction, pollution by use of chemicals, discharge of nutrients, microbial pathogens, drugs, herbicides and fungicides (Spalding, 2016) ${ }^{12}$. Even from land based aquaculture projects, the possibility is there for these pollutants to enter the ocean through streams or with rainwater. This can have an adverse impact on the fisheries in coastal regions.

d. Shipping. Shipping is considered as the most 'carbon efficient' means of transportation of goods. The situation has further improved with Triple E class (Economy of scale, Energy efficient and environmentally friendly) mega container vessels coming into operation. However, shipping is still a substantial emitter of greenhouse gasses, acoustic pollution, oil spills and other types of pollution. Shipbreaking can be a dangerous

12 Mark J. Spadling, "The New Blue Economy: The Future of Sustainability", Journal of Oceans and Coastal Economics, 2, no.2, (2016). 
industry unless properly regulated and safety standards are scrupulously met. There can be many toxic materials, which had been used in ship construction, especially in older ships, such as asbestos. Asbestos fiber can enter the human respiratory track through inhalation causing cancer. Ships are coated with tons of paint containing lead, cadmium, organotin, arsenic, zinc and chromium. There also can be various sealants used in PCBs. These are considered as hazardous waste and remain intact in the environment for long periods. These could be distributed widely and can enter the humans and other mammals, fish and other animals through the food chain.

Ships also contain large quantities of residual oils and lubricants. These can be spilled and mix with the seawater and left floating along the seashore. These spills can reduce the light intensity beneath the water, which inhibit photosynthesis, restrict the exchange of oxygen and carbon dioxide, which can be harmful to aquatic life and cause damage to the bird population by coating their feathers and causes buoyancy and insulation losses 13 . Finally, the ship breaking can lead to severe labour abuses and minimal environmental mitigation. This activity can pollute beaches and coastal waters and have human security implications, especially in coastal communities.

e. Coastal Tourism. Coastal tourism is a major industry in many of the coastal countries. There can be unsustainable and disruptive tourist activities taking place in these areas. Spalding says "many coastal regions around the world are under siege from the impact of inappropriate tourism development" (2016) ${ }^{12}$. Unauthorized construction of infrastructure, discharge of untreated sewage and some other coastal tourist activities have led to coastal erosion, depletion of mangrove plantations and seriously threaten local fish, wildlife and their habitats. This can affect the livelihood of coastal population and also one of the main attractions that tourists come for.

${ }^{13}$ Hossain, M.M., \& Isalam, M.M. “Environmental Pollution: Ship Breaking in Bangladesh, Young Power In Social Action (YPSA), https://www.shipbreakingbd.info/Environment.html 
f. Climate Change and Global Warming. It is likely that the biological, social and economic aspects related to fishing may be highly sensitive to climate change and global warming. As per a report released by United Nations FAO "Climate change is already impacting the world's oceans and will have serious consequences for the hundreds of millions of people who depend on fishing for their livelihoods" (2008) ${ }^{14}$. Changes in sea temperature would alter the body temperature of many aquatic species and could impact their metabolism, reproduction cycle, growth rate and even susceptibility to diseases and toxins. There can be changes in salinity due to melting ice and precipitation, which would impact the fisheries.

\section{Conclusion on Fisheries Management: The Way Forward}

The Indian Ocean is a vast and warm water ocean, which is home to large fish stocks. Despite all the international instruments, conventions and activities of international organizations, threats to sustainable fisheries management continues, in particular overfishing, IUU fishing and destructive fishing practices. There are a number of maritime border disputes in this region and quite often fishermen from one country ventures to the waters of another and get arrested.

Fishermen are the only category of people who can leave the shores of a country without any immigration or customs control and return back to the shores. Fishermen do not restrict their fishing to territorial waters or even to the EEZ. They fish in international waters and even in the EEZ of other states at times. This situation gives them a unique advantage of leaving a country, staying at sea for a number of days and return back to the country without proper checks been made by enforcement authorities. There are many instances of fishermen being engaged in smuggling of contrabands, narcotic substances, weapons and even humans. There have been instances of fishing crafts have been exploited by terrorist organizations to carry out their missions.

Threats to sustenance of fisheries in the Indian Ocean fisheries can come from many man-made and natural phenomena. Oil and gas

14 United Nations News Centre, "Climate Change will have Major impact on Fishing Industry," (2008),

NewsID=27330\#.WHIPRvl97IU

://www.un.org/apps/news/story.asp? 
industry, over fishing and IUU fishing, shipping and coastal tourism can have a negative impact on fisheries. However, the worst enemy of the fisheries may be the climate change and global warming and the resultant rise in sea temperatures and changes in salinity.

There is no doubt that the Blue Economy is the way forward for the humankind in the next decades to come. The humankind has no alternative but to use the blue economic activities to sustain and prosper. However, it must be understood that even the vast oceans contain finite resources only and any exploitation or extraction has to be made keeping this in mind. Even a living source like fish need time to recover. Unless the world exploits the oceans in the sustainable manner, the worst affected will be the coastal communities. The livelihood of this community depends heavily on the resources they harvest from the oceans. In order to understand the way forward in coastal management, the Goal 14 of the United Nations resolution 70/1, "Transforming our world: The 2030 Agenda for Sustainable Development" can be used. The main objective of Goal 14 of this agenda, 'Life Below Water' is to "conserve and sustainably use oceans, seas and marine resources for sustainable development" (UN, 2015) ${ }^{15}$.

The states will have to work together for mutual betterment and to ensure sustainable exploitation of fisheries resources. The states will also have to ratify and implement international instruments governing sustainable fishing. The Regional Fisheries Management Organizations should play a more effective role in the management of fisheries. It is also necessary to implement modern fisheries management tools.

15 United Nations, Sustainable Development Goals, (2015). https://sustainabledevelopment.un.org/sdg14 